\title{
UPAYA MENINGKATKAN KEMAMPUAN BERBAHASA ANAK MELALUI METODE BERCERITA DI TK MIFTAHUL KHAIR
}

\author{
${ }^{1}$ Hamsiani, Syamsul Alam Ramli ${ }^{2}$ \\ ${ }^{1}$ TK Miftahul Khair Kab. Luwu, ${ }^{2}$ Universitas Muhammadiyah Palopo \\ ${ }^{1}$ Email: hamsianiani6@gmail.com \\ ${ }^{1}$ Orcid Id: https://orcid.org/0000-0002-3538-2796
}

\begin{abstract}
Article received : 2020-12-20
Review process : 2020-12-21

Article published : 2020-12-29
\end{abstract}

\begin{abstract}
This research is a classroom action research which examines 13 children of TK Miftahul Khair in Limbong Village in the academic year 2020/2021 related to children's language learning through storytelling methods. The goal to be achieved is to improve children's language skills in composing sentences through the storytelling method. The method used is classroom action research with data collection using observation sheets. The collected data were analyzed using quantitative descriptive statistics. So based on the results of the overall study of 13 children, the results of children's language skills in cycle I were 63\% and cycle II was 84\%, so there was an increase of $21 \%$. Based on the results of this study, it can be concluded that the storytelling method can improve children's language skills.
\end{abstract}

Keywords: Language Skills, Storytelling Methods

\begin{abstract}
Abstrak
Masalah penelitian ini tentang penyalahgunaan media sosial yang megakibatkan siswa tidak Penelitian ini merupakan penelitian tindakan kelas yang menguji terhadap 13 orang anak TK Miftahul Khair Desa Limbong tahun ajaran 2020/2021 terkait dengan pembelajaran bahasa anak melalui metode bercerita. Adapun tujuan yang hendak dicapai adalah untuk meningkatkan kemampuan berbahasa anak dalam menyusun kalimat melalui metode bercerita. Metode yang digunakan adalah penelitian tindakan kelas dengan pengumpulan data menggunakan lembar observasi. Data yang terkumpul dianalisis menggunakan statistik deskriptif kuantitatif. Maka berdasarkan pada hasil penelitian secara keseluruhan dari 13 orang anak bahwa hasil kemampuan berbahasa anak pada siklus I sebesar $63 \%$ dan siklus II sebesar $84 \%$, jadi terdapat peningkatan $21 \%$. Berdasarkan pada hasil penelitian tersebut maka hasil penelitian ini dapat disimpulkan bahwa metode bercerita dapat meningkatkan kemampuan berbahasa anak.
\end{abstract}

Kata Kunci: Kemampuan Berbahasa, Metode Bercerita 


\section{Pendahuluan}

Pendidikan Anak Usia Dini (PAUD) adalah pendidikan untuk anak usia 0-6tahun. Pada usia anak tersebut dipandang mempunyai karakteristik yang berbeda dengan anak usia di atasnya supaya pendidikannya perlu dikhususkan. PAUD bertujuan mengembangkan seluruh potensi anak supaya nantinya mampu berfungsi sebagai manusia yang total berdasarkan falsafah suatu bangsa (Sunaryanto, 2015).

Pendidikan anak usia dini di Taman Kanak-Kanak merupakan satu di antara jenjang pendidikan pada jalur formal. Peran pokok Taman Kanak-Kanak adalah mempersiapkan anak dengan memperkenalkan beragam pengetahuan, sikap perilaku, keterampilan dan intelektual supaya mampu melakukan adaptasi dengan kegiatan yang sesungguhnya di Sekolah Dasar. Hal ini juga sesuai dengan amanat Undang-Undang Nomor 20 Tahun 2003 tentang Sistem Pendidikan Nasional, pada pasal 1 angka 14 menyatakan bahwa pendidikan anak usia dini adalah suatu tindakan pembinaan yang ditujukan kepada anak sejak lahir sampai dengan usia enam tahun yang dilakukan melalui pemberian rangsangan pendidikan untuk membantu pertumbuhan dan perkembangan jasmani dan rohani supaya anak memiliki kesiapan dalam memasuki pendidikan lebih lanjut (Departemen Pendidikan Nasional, 2018:1).

Maka berdasarkan pada berdasarkan Peraturan Mentri Pendidikan dan Kebudayaan Nomor 137 Tahun 2014 tentang standar tingkat pencapaian perkembangan bahasa anak usia 5-6 Tahun pada kurikulum pendidikan terdapat enam aspek perkembangan yang dapat dikembangkan yaitu: pertama perkembangan nilai-nilai agama dan moral, kedua perkembangan aspek fisik motorik, ketiga aspek perkembangan bahasa, keempat aspek perkembangan kognitif, kelima aspek perkembangan sosial emosional, keenam aspek perkembangan seni.

Aspek perkembangan bahasa merupakan bahasa memiliki peran yang sangat penting dalam tumbuh kembang anak karena bahasa dan keaksaraan merupakan proses yang terjadi sepanjang hayat dan sejak anak dilahirkan. Fungsi utama dari bahasa adalah membantu seseorang untuk berinteraksi dan berkomunikasi dengan orang lain (Winda Gunardi 2017:75). Ketika seorang anak mampu menyusun kalimat maka ia mampu berkomunikasi dengan teman atau orang-orang disekitarnya. Bahasa merupakan bentuk utama dalam mengekspresikan pikiran dan pengetahuan bila anak mengadakan hubungan dengan orang lain. Anak yang sedang tumbuh dan berkembang mengkomunikasikan kebutuhan, pikiran dan perasaannya melalui bahasa dengan kata-kata yang mempuyai makna.

Pengembangan berbahasa menurut Dahlan dalam Danim (2014:3) mempunyai empat komponen yang terdiri dari pemahaman, pengembangan perbendaharaan kata, penyusunan kata-kata menjadi kalimat dan ucapan. Keempat pengembangan tersebut memiliki hubungan yang saling terkait satu sama lain, yang merupakan satu kesatuan. Keempat keterampilan tersebut perlu dilatih pada anak usia dini karena dengan kemampuan menyusun kalimat sederhana tersebut anak akan belajar berkomunikasi dengan orang lain, sebagaimana dalam kurikulum K-13 diungkapkan bahwa kompetensi dasar dari pengembangan bahasa untuk anak usia dini yaitu anak mampu mendengar, berkomunikasi secara lisan, memiliki perbendaharaan kata, dan mengenal simbol-simbol yang melambangkannya.

Mengingat bahasa itu merupakan sistem lambang, maka manusia mampu berfikir dan berbicara tentang sesuatu yang abstrak, di samping yang konkret. Anak-anak sebelum memasuki dunia pendidikan ada kecenderungan menggunakan bentuk-bentuk bahasa yang mampu dipahami oleh orang tuanya dan orang-orang yang ada di sekitarnya (Mulyadi 2015:18). Menurut Winda Gunardi (2014:1.35) bahwa ada empat macam kemampuan berbahasa anak yaitu menyimak, berbicara, membaca, dan menulis. Bahasa merupakan suatu sistem tata yang relatif rumit dan bersifat semantik (tata kata dan kalimat). Bahasa ada yang 
bersifat reseptif (dimengerti dan diterima) seperti mendengarkan dan membaca suatu informasi, juga ada yang bersifat ekspresif (dinyatakan) seperti berbicara dan menuliskan suatu informasi.

Oleh karena itu kemampuan berbahasa pada anak usia dini maupun setelah remaja kelak akan berpatokan pada perolehan kemampuan bahasa yang didapat senjak saat sekarang, maka akan menjadikan kesuksesan dalam berbahasa di masa depannya. Kemampuan menyusun kalimat sederhana di Taman Kanak-kanak Miftahul Khair masih minim. Hal tersebut dibuktikan pada tahun ajaran sebelumnya anak-anak di kelompok B masih banyak yang belum mampu berbahasa dengan fasih lancar.

Pada pedoman guru TK diungkapkan jika pada pelaksanaan pembinaan dan perkembangan bahasa di TK sebaiknya memperhatikan prinsip-prinsip dengan memberikan kesempatan sebaik-baiknya pada anak guna mengembangkan aspek perkembangan dan hendaknya spontanitas anak sebaiknya bukan ditekan dan sebaiknya diberikan pada suasana keakraban antara anak dengan guru, juga terpenuhinya syarat-syarat yang diambil dari lingkungan anak, sesuai dengan tahapan usia dan tahapan perkembangan anak agar komponen perkembangan anak mampu tercapai secara lebih baik.

Bahasa sebagai alat komunikasi diperoleh manusia sejak lahir sampai usia lima tahun, yang dikenal dengan istilah pemerolehan bahasa. Menurut pendekatan teoritis terhadap perkembangan bahasa anak mampu terjadi secara alami merupakan bawaan sejak lahir, untuk mengembangkan kemampuan tersebut diperlukan penguatan atau stimuli, baik dari lingkungan keluarga maupun dari lingkungan sekolah dan lingkungan masyarakat. Menurut Nurbiana Dhieni (2017: 31) salah satu hal yang paling pesat dalam perkembangan balita adalah kemampuan berbahasa. Masa balita sangat tepat untuk belajar bahasa karena masih sedikitnya perbendaharaan kata-kata yang dimiliki anak. Anak yang dibesarkan dalam lingkungan bahasa tertentu akan menjadi fasih dengan bahasa tertentu. Pengembangan bahasa untuk anak usia $4-6$ tahun (usia TK) difokuskan pada aspek menyimak, berbicara, menulis, membaca dengan menggunakan bahasa untuk berkomunikasi dengan orang lain, anak akan menmampukan banyak sekali kosa kata, sekaligus mampu mengekspresikan dirinya. Dengan kata lain pengembangan bahasa lebih diarahkan supaya anak mampu: (1) mengolah kata secara komprehensif. (2) mengekspresikan katakata tersebut dalam bahasa tubuh (ucapan dan perbuatan) yang mampu dipahami oleh orang lain. (3) mengerti setiap kata, mengartikan dan menyampaikannya secara utuh kepada orang lain. (4) berargumentasi, meyakinkan orang melalui kata-kata yang diucapkannya.

Pada minggu pertama masuk sekolah anak sudah mulai dilihat kemampuan berbahasanya dengan cara diajarkan berkenalan dengan teman dan dengan guru. Anak juga dilatih untuk mampu menjawab pertanyaan-pertanyaan yang diajukan padanya, baik itu pertanyaan dari teman maupun dari guru. Selain itu anak diberi kesempatan untuk bercerita tentang keluarga, teman di rumah, hobi/kesukaan, tempat tinggal dan lain-lain. Karena itu pengembangan kemampuan berbahasa disusun sedemikian rupa sehingga mampu memenuhi kebutuhan anak. Meta Novtrya Sari, (2014:17-18) dalam skripsinya bahwa ruang lingkup pengembangan kemampuan berbahasa di Taman Kanak-kanak mencakup pengembangan dan peningkatan berbahasa dalam:

1. Berbicara

Berbicara (dalam rangka keterampilan bahasa lisan, melatih cara berpikir dan membentuk konsep). Kemampuan ini mampu dicapai melalui kegiatan-kegiatan yang merangsang minat anak untuk berbicara, misalnya dengan pancingan pertanyaan tentang kegiatan sehari-hari, menyebutkan nama benda-benda/gambar, menangkap isi cerita, berdialog, bercakap-cakap dengan teman, bercerita dan sebagainya. Secara umum melalui 
kegiatan mendengar dan berbicara diharapkan anak mampu: a. Berbicara dengan penuh percaya diri. b. Menggunakan bahasa untuk memperoleh informasi dan untuk komunikasi yang efektif dan interaksi sosial dengan yang lain. c. Menikmati buku, cerita dan irama. d. Mengembangkan kesadaran bunyi.

2. Mendengarkan

Mendengarkan (melatih anak menagkap dan memahami pembicaraan lain). Hal ini mampu dicapai melalui kegiatan-kegiatan, seperti mendengarkan cerita guru, mendengarkan cerita temantemannya, menerima dengan baik pesan yang disampaikan kepadanya, menanggapi suatu cerita, mendengarkan dengan sungguh-sungguh dan merespon dengan tepat, dan sebagainya.

3. Mengembangkan kosa kata

Mengembangkan kosa kata (dengan memperkenalkan berbagai jenis kata dalam bentuk kegiatan sehari-hari). Misalnya namanama binatang di sekitarnya, mengenalkan gambar-gambar dan menceritakan isi gambar, mengenalkan konsep waktu dan ruang, mengenalkan kata sambung, kata penghubung, kata imbuhan, kata sifat dan sebagainya.

Menurut Miftahul Huda (2015:12) metode yang akan digunakan dalam program kegiatan anak di Taman Kanak-kanak dapat mempunyai alasan yang kuat dan faktor-faktor yang mendukung pemilihan metode tersebut, seperti karakteristik tujuan kegiatan dan karakteristik anak yang diajar. Yang dimaksud karakteristik tujuan adalah pengembangan kreativitas, pengembangan emosi, pengembangan motorik dan pengembangan nilai serta pengembangan sikap dan nilai. Untuk mengembangkan kreativitas anak, metode-metode yang digunakan adalah metode-metode yang mampu menggerakkan anak untuk meningkatkan motivasi rasa ingin tahu dan mengembangkan imajinasi. Untuk mengembangkan emosi anak dengan menggunakan metode-metode yang menggerakkan anak, mengekspresikan perasaan yang menyenangkan dan tidak menyenangkan secara verbal dan tepat.

Guna mengembangkan kemampuan motorik anak mampu digunakan metode-metode yang menjamin anak tidak mengalami cedera, oleh karena itu perlu menciptakan lingkungan aman dan menantang, dan alat yang dipergunakan dalam keadaan baik,tidak menimbulkan perasaan takut dan cemas dalam menggunakannya. Untuk mengembangkan nilai dan sikap anak mampu dipergunakan metode berbentuk kebiasaan-kebiasaan yang didasari nilai-nilai agama dan moral pancasila supaya anak mampu menjalani hidup sesuai dengan norma yang dianut dalam masyarakat seperti kebiasaan kerja, menghargai waktu, dan kebiasaan memelihara lingkungan (Danim 2014:17).

Berdasarkan argumen di atas, penulis menyimpulkan manfaat bercerita adalah untuk mengembangkan aspek-aspek perkembangan anak dan untuk mengembangkan potensi kreatif anak melalui keragaman ide yang diaturkan. Metode bercerita dalam kegiatan pengajaran anak TK mempunyai beberapa manfaat penting bagi pencapaian tujuan pendidikan TK. Menurut Nurbiana Dhieni (217:58) tekhnik yang mampu digunakan dalam menerapkan metode bercerita adalah: (1) Membaca langsung dari buku cerita, (2) Bercerita dengan menggunakan ilustrasi gambar dari buku, (3) Bercerita dengan menggunakan papan planel, (4) Bercerita dengan menggunakan media boneka dan (5) bermain peran dalam suatu cerita.

Menurut Widia Pekerti (2017:34) penerapan kegiatan bercerita mampu dilakukan dengan berbagai bentuk, seperti:

1. Bercerita tanpa alat peraga hanya akan mengandalkan kemampuan verbal orang yang memberikan cerita; 
2. Bercerita dengan menggunakan alat peraga seperti boneka, gambar-gambar dan benda lain;

3. Bercerita dengan cara menggunakan buku cerita (story reading dalam hal ini tidak diperlukan kemampuan fantasi, imajinasi, dan olah kata dari orang-orang yang bercerita, melainkan hanya oleh intonasi dan suara;

4. Bercerita dengan menggunakan bahasa isyarat atau gerakan seperti pantomim, film kartun tanpa bicara, opera dan sebagainya;

5. Bercerita melalui alat pandang (Audio Visual) yaitu mampu berupa kaset, televisi, video, dan sebagainya. Bagi anak usia TK mendengarkan cerita yang menarik yang dekat dengan lingkungannya merupakan kegiatan yang mengasyikkan.

Guru TK yang terampil bertutur dan kreatif dalam bercerita mampu menggetarkan perasaan anak. Guru mampu memanfaatkan kegiatan bercerita untuk menanamkan kejujuran, keberanian, kesetiaan, keramahan, ketulusan, sikap-sikap positif yang lain dalam kehidupan lingkungan keluarga, sekolah, dan luar sekolah. Kegiatan bercerita juga memberikan sejumlah pengetahuan sosial, nilai-nilai moral, dan keagamaan. Kegiatan bercerita memberikan pengalaman belajar untuk berlatih mendengarkan. Melalui pendengaran anak memperoleh bermacam informasi tentang pengetahuan, nilai, dan sikap untuk dihayati, dan diterapkan dalam kehidupan sehari-hari. Memberi pengalaman belajar dengan menggunakan metode bercerita memungkinkan anak untuk mengembangkan kemampuan kognitif, efektif, maupun psikomotor masing-masing anak.

Bila anak terlatih untuk mendengarkan dengan baik, maka ia akan terlatih untuk menjadi pendengar yang kreatif dan kritis. Pendengar yang kreatif mampu melakukan pemikiran-pemikiran baru berdasarkan apa yang didengarkannya. Pendengar yang kritis mampu menemukan ketidak sesuaian antara apa yang didengar dengan apa yang dipahami.

Kegiatan bercerita memberikan pengalaman belajar untuk melatih mendengarkan. Melalui mendengarkan untuk memperoleh bermacam-macam informasi tentang pengetahuan, nilai dan sikap untuk dihayati serta mampu mengkomunikasinya dengan bahasa yang baik dan benar. Memberi pengalaman belajar dengan metode bercerita memungkinkan anak mengembangkan kemampuan kognitif, efektif, maupun psikomotor masing-masing anak. Metode bercerita ini juga merupakan peluang bagi anak mampu mempraktekkan bahasa yang benar dalam kehidupan sehari-hari (Danim 2014:36).

\section{Metode Penelitian.}

Penelitian Tindakan Kelas (PTK) adalah model penelitian yang dilakukan ini. Penelitian ini adalah dengan mengidentifikasi sebagai suatu penelitian tindakan (action research) dimana dilakukan oleh peneliti sebagai guru di kelasnya atau berkolaborasi sacara bersama orang lain melalui upaya merancang, melaksanakan dan merefleksikan tindakan secara bersama-sama serta partisipatif dengan tujuan dalam rangka memperbaiki juga melalui tindakan meningkatkan mutu proses pembelajaran di kelasnya.( Wardani, I.G.A.K, 2017:17).

Secara sederhana siklus PTK mampu digambarkan sebagai berikut:

\section{Tahap Perencanaan (Planning)}

Pada tahap ini, peneliti menjelaskan tentang mengapa (why), dimana (where), kapan (when), apa (what), dan bagaimana (how) penelitian dilakukan. Penelitian tindakan kelas seyogyanya dilaksanakan dengan cara kolaboratif, agar mencegah aspek subjektivitas peneliti. Pada penelitian tindakan kelas, ada kegiatan pengamatan atau observasi terhadap diri sendiri, yaitu ketika peneliti menggunakan pendekatan, model, atau metode pembelajaran sebagai upaya tindakan menyelesaikan masalah ketika praktik penelitian. 
Dibutuhkan teman sejawat guna menilai kegiatan tersebut. Pelaksanaan pada tahapan perencanaan, peneliti lakukan dengan persiapan-persiapan pelaksanaan penelitian, yaitu rencana pelaksanaan pembelajaran dan instrumen pengamatan (observasi).

\section{Tahapan Pelaksanaan (Acting)}

Pada tahapan pelaksanaan, dilaksanakan langkah implementasi atau penggunaan perencanaan tindakan adalah pembelajaran bahasa melalui metode bercerita pada anak TK Miftahul Khair Desa Limbong. Ada pelaksanaan kegiatan ini, peneliti mengikuti perencanaan yang telah dibuat. Dengan demikian pada tahapan ini agar pembelajaran dapat berjalan normal seperti biasanya sesuai dengan rencana pembelajaran. Upaya pengamatan secara objektifitas berdasarkan situasi pembelajaran yang dilakukan peneliti. Kegiatan ini penting guna pencapaian penelitian tindakan kelas serta untuk memperbaiki kegiatan pembelajaran.

\section{Tahapan Pengamatan (Observing)}

Kegiatan tahapan pengamatan terdapat dua hal yang perlu untuk diamati, yaitu pelaksanaan pembelajaran bercerita anak dan aktivitas belajar anak TK Miftahul Khair Desa Limbong. Pengamatan tpada kegiatan belajar peserta didik dilaksanakan sendiri oleh peneliti ketika melakukan pembelajaran. Adapun pengamatan pada kegiatan pembelajaran, peneliti akan meminta partisifasi teman sejawat yang berposisi selaku kolaborator guna melakukan kegiatan pengamatan. Kolaborator ini melakukan pengamatan pembelajaran sesuai dengan instrumen yang telah peneliti susun. Hasil pengamatan dari parner kelak akan bermanfaat atau akan dipakai oleh peneliti menjadi bahan refleksi pada perbaikan kegiatan pembelajaran yang selanjutnya.

\section{Tahapan Refleksi (Reflecting)}

Kegiatan refleksi dilakukan saat parner telah selesai pada pengamatannya kepada peneliti ketika melaksanakan kegiatan pembelajaran. Kegiatan ini dapat dalam bentuk diskusi hasil pengamatan yang dilaksanakan oleh parner bersama peneliti. Tahapan ini adalah jantung daripada penelitian tindakan kelas, yaitu ketika parner menyampaikan sesuatu yang dianggap telah berjalan bagus serta hal yang belum terlaksana secara bagus ketika peneliti melakukan aktivitas pembelajaran. Penilaian pada refleksi kemudian dijadikan sebagai modal pertimbangan saat menyusun siklus pembelajaran berikutnya. Maka pada dasarnya, refleksi tidak lain adalah proses evaluasi, penyimpulan, penjelasan, pemaknaan, identifikasi, dan analisis tindak lanjut pada perencanaan siklus selanjutnya (Agus Riyanto, 2016).

\section{Hasil dan Pembahasan}

Mendasarkan data perolehan pada siklus I dan siklus II memberikan bahwa metode bercerita dalam hal ini menggunakan boneka jari menadikan anak-anak akan semakin bersemangat saat menerima materi dari peneliti. Pada siklus I telah terlihat perubahan peningkatan kemampuan anak dalam menyusun kalimat sederhana, hanya saja perubahan tersebut masih didominasi dengan kemampuan anak dengan berkembang sesuai harapan. Harapan peneliti bahwa anak dapat berkembang sangat baik. Juga pada siklus I sejumlah anak masih malu-malu saat diminta untuk berbicara khususnya menceritakan ulang cerita yang telah penulis sampaikan. Juga perhatian anak yang belum sepenuhnya serius dikarenakan terkadang mereka cerita dengan teman di sampingnya. Sehingga pada siklus II 
dilakukan tindakan-tindakan perbaikan supaya kondisi yang diharapkan melalui penelitian ini dapat tercapai.

Berikut dipaparkan perbandingan pencapaian pada setiap siklus pra siklus, siklus I, dan siklus II:

Tabel 1: Perbandingan Hasil Pra Siklus, Siklus I, dan Siklus II

\begin{tabular}{|c|c|c|c|c|c|c|c|}
\hline \multirow[b]{2}{*}{ No } & \multirow[b]{2}{*}{ Nama } & \multicolumn{2}{|c|}{ Pra Siklus } & \multicolumn{2}{|c|}{ Siklus I } & \multicolumn{2}{|c|}{ Siklus II } \\
\hline & & Skor & Inter & Skor & Inter & Skor & Inter \\
\hline 1 & As & 4 & BB & 8 & MB & 12 & BSH \\
\hline 2 & $\mathrm{Al}$ & 4 & $\mathrm{BB}$ & 8 & MB & 12 & BSH \\
\hline 3 & $\mathrm{Au}$ & 6 & MB & 11 & $\mathrm{BSH}$ & 15 & BSB \\
\hline 4 & $\mathrm{Dh}$ & 4 & BB & 10 & $\mathrm{BSH}$ & 13 & BSB \\
\hline 5 & $\mathrm{Fe}$ & 6 & MB & 13 & BSB & 16 & BSB \\
\hline 6 & Hf & 4 & BB & 12 & $\mathrm{BSH}$ & 15 & BSB \\
\hline 7 & $\mathrm{Hh}$ & 4 & BB & 9 & $\mathrm{BSH}$ & 14 & BSB \\
\hline 8 & Iv & 5 & MB & 11 & BSB & 15 & BSB \\
\hline 9 & $\mathrm{Ag}$ & 4 & $\mathrm{BB}$ & 10 & $\mathrm{BSH}$ & 12 & $\mathrm{BSH}$ \\
\hline 10 & Lh & 6 & MB & 11 & $\mathrm{BSH}$ & 13 & BSB \\
\hline 11 & Mf & 4 & BB & 11 & $\mathrm{BSH}$ & 14 & BSB \\
\hline 12 & Ms & 4 & BB & 11 & $\mathrm{BSH}$ & 15 & BSB \\
\hline 13 & $\mathrm{Nr}$ & 4 & BB & 7 & MB & 9 & $\mathrm{BSH}$ \\
\hline $\begin{array}{c}\text { Jum } \\
\text { BB }\end{array}$ & lah & 9 & $70 \%$ & 0 & $0 \%$ & 0 & $0 \%$ \\
\hline $\begin{array}{l}\text { Jum } \\
\text { ME }\end{array}$ & $\begin{array}{l}\text { nlah } \\
\text { B }\end{array}$ & 4 & $30 \%$ & 3 & $23 \%$ & 0 & $0 \%$ \\
\hline $\begin{array}{l}\text { Jum } \\
\text { BSF }\end{array}$ & $\begin{array}{l}\text { alah } \\
\text { H }\end{array}$ & 0 & $0 \%$ & 8 & $62 \%$ & 4 & $30 \%$ \\
\hline $\begin{array}{c}\text { Jum } \\
\text { BS }\end{array}$ & $\begin{array}{l}\text { nlah } \\
\text { B }\end{array}$ & 0 & $0 \%$ & 2 & $15 \%$ & 9 & $70 \%$ \\
\hline & Total & 13 & $\begin{array}{c}100 \\
\%\end{array}$ & 13 & $100 \%$ & 13 & $100 \%$ \\
\hline
\end{tabular}

Berdasarkan hasil pengamatan dapat dilihat bahwa dengan bercerita dapat meningkatkan kemampuan berbahasa anak. Hal ini dapat dilihat dari hasil yang diperoleh siswa dari pra siklus kriteria kemampuan bercerita anak belum berkembang (BB) atau sebesar $70 \%$, pada observasi siklus I dan II menjadi $0 \%$. Maka sejak pembelajaran pertama 
yaitu pada siklus I, sebenarnya sudah tidak ada lagi anak yang belum berkembang kemampuan berbicaranya. Pada observasi pra siklus ada empat anak mempunyai kriteria berbahasa mulai berkembang (MB) atau sebesar 30\%, pada observasi siklus I jumlah tersebut berkurang menjadi tiga orang anak atau sebesar 23\%. Terdapat mutasi dari siswa yang sebelumnya mulai berkembang menjadi kemampuan yang lebih di atasnya lagi. Hal ini sangat terlihat pada siklus II jumlah tersebut berkurang menjadi $0 \%$ dikarenakan sebagian dari anak-anak tersebut mengalami perkembangan bahasa dengan kriteria berkembang sesuai harapan dan berkembang sangat baik. Secara keseluruhan dari 13 orang anak bahwa hasil kemampuan berbahasa anak pada siklus I sebesar $63 \%$ dan siklus II sebesar $84 \%$, jadi terdapat peningkatan $21 \%$.

Kondisi kemampuan berbahasa pada anak pada observasi pra siklus dengan kriteria berkembang sesuai harapan (BSH) sebesar $0 \%$ dari jumlah siswa pada kelas tersebut, pada hasil observasi siklus I meningkat menjadi $62 \%$ terjadi loncatan peningkatan besar dari kondi sebelumnya belum berkembang dan mulai berkembang. Puncaknya pada siklus II jumlah tersebut mengalami penurunan yang tersisa yaitu sebesar 30\%. Hal ini karena anak terus mengalami peningkatan kemampuan. Dapat dilihat bahwa pada observasi pra siklus untuk kriteria berkembang sangat baik (BSB) belum ada siswa yang mencapainya, pada siklus I sebanyak $15 \%$ anak mencapai kriteria tersebut, dan pada selanjutnya pada siklus II bertambah menjadi $70 \%$. Terjadi peningkatan dari siklus I ke siklus II dengan kondisi anak berkembang sangat baik (BSB) dengan peningkatan sebesar $55 \%$. Berdasarkan pada hasil penelitian tersebut maka hasil penelitian ini dapat disimpulkan bahwa metode bercerita dapat meningkatkan kemampuan berbahasa anak

\section{Simpulan}

Penelitian ini merupakan penelitian tindakan kelas yang menguji terhadap 13 orang anak TK Miftahul Khair Desa Limbong tahun ajaran 2020/2021. Penelitian terkait dengan pengujian terhadap tindakan meningkatkan kemampuan berbahasa pada anak dengan menggunakan metode bercerita. Maka berdasarkan pada hasil penelitian tersebut dengan menggunakan dua siklus pembelajaran yairu siklus I dan II dengan hasil akhir diketahui sebanyak 30\% anak berada pada kategori berkembang sesuai harapan (BSH) dan sebanyak $70 \%$ pada kategori berkembang sangat baik (BSB), terjadi peningkatan sebesar 55\% dari siklus I ke siklus II. Sehingga hasil penelitian ini dapat disimpulkan bahwa metode bercerita dapat meningkatkan kemampuan berbahasa anak

\section{Daftar Rujukan}

Sunaryanto, Muhammad. (2015). Tindakan Meningkatkan Kemampuan Bahasa Anak Usia 5-6 Tahun, http://eprints.uny.ac.id/22060/1/jurnalpendidikan vol-05 \%20 \%20muhammad \%20sunaryanto.diakses 03 Februari 2020.

Depdiknas. 2018. Pedoman umum sistem pengujian hasil kegiatan belajar, diakses dari internet, www. google.com, tanggal 20 Desember 2020.

Gunadi, Winda. 2017. Metode Pengembangan Perilaku dan Kemampuan Dasar Anak Usia Dini, Semarang: UT.

Danim, Sudarwan. 2014. Psikologi Pendidikan dalam Perspektif Baru, Bandung: Alfabeta. Meta Novtrya Sari. 2014. Meningkatkan Kemampuan Berbahasa Anak Melalui Metode Bercerita Di Kelompok B TK Yasporbi Kota Bengkulu. Skripsi: http://repository.unib.ac.id/8675/2/I\%2CII\%2CIII\%2CII-14-met.FK.pdf.

Mulyadi. 2015. Psikologi Belajar, Yogyakarta: Andi Offset. 
Gunardi, Winda, dkk. 2014. Metode Pengmbangan Perilaku dan Kemampuan Dasar Anak Usia Dini, Tangerang: UT.

Danim, Sudarwan. 2014. Psikologi Pendidikan dalam Perspektif Baru, Bandung: Alfabeta. Pekerti, Widia, dkk. 2017. Metode Pengembangan Seni, Semarang: UT.

Wardani, IGAK. 2017. Penelitian Tindakan Kelas, Tangerang: UT.

Riyanto, Agus. 2016. Mengenal Tahapan Siklus Penelitian Tindakan Kelas. https://www.amongguru.com/mengenal-tahapan-siklus-penelitian-tindakan-kelasptk/ diakses pada 10 Februari 2020. 